\title{
Obesity-associated gene FTO rs9939609 polymorphism in relation to the risk of tuberculosis
}

Yan Feng ${ }^{1,2 \dagger}$, Fengliang Wang ${ }^{3 \dagger}$, Hongqiu Pan ${ }^{4}$, Sangsang Qiü ${ }^{2}$, Jieqiong L $\ddot{2}^{2}$, Liang Wu ${ }^{2}$, Jianming Wang ${ }^{2^{*}}$ and Cheng $\mathrm{Lu}^{3^{*}}$

\begin{abstract}
Background: Obesity is known to affect cell-mediated immune responses. Recent studies have revealed that genetic polymorphisms in the fat mass and obesity associated (FTO) gene are related to human obesity. We hypothesize that this gene may also play a role in the risk of immune-related infectious diseases such as tuberculosis.

Methods: This case-control study included 1625 pulmonary tuberculosis cases and 1570 unaffected controls recruited from the Jiangsu province in China. Single nucleotide polymorphisms (SNPs), rs9939609 and rs8050136, in the FTO gene were genotyped using TaqMan allelic discrimination assays. Odds ratios (ORs) and 95\% confidence intervals (Cls) were calculated using the unconditional logistic regression model.

Results: We observed a significant association between the genetic polymorphism rs9939609 and tuberculosis risk. Compared with the common genotype $\Pi$, individuals carrying AA had a significantly increased risk, with an OR of 3.77 (95\% Cl: 2.26-6.28). After adjusting for potential confounders, the relationship remains significant. An additive model showed that carriers of an allele A had a 26\% increased risk of tuberculosis compared with the T allele (OR: 1.26, 95\% Cl: 1.08-1.48). Compared with the common haplotype rs9939609T-rs8050136C, the haplotype rs9939609A-rs8050136C was related to an increased risk of tuberculosis ( $\mathrm{OR}=6.09,95 \% \mathrm{Cl}$ : 3.27-12.34).
\end{abstract}

Conclusions: The FTO polymorphism rs9939609 is associated with a risk of pulmonary tuberculosis in the Chinese population.

\section{Background}

Tuberculosis (TB), a chronic infectious disease caused by Mycobacteria tuberculosis and continues to be a major global health threat, particularly in developing countries. In 2012, an estimated 8.6 million new cases occurred, and approximately 1.3 million people died worldwide due to TB (WHO. Global tuberculosis report 2013). Malnutrition, tobacco smoking, immunosuppressive treatment, diabetes, indoor air pollution, crowding, migration, aging and poverty have all been recognized as possible risk factors [1-5]. Among these factors, weight-related problems

\footnotetext{
* Correspondence: jmwang@njmu.edu.cn; lucheng66@126.com

${ }^{\dagger}$ Equal contributors

${ }^{2}$ Department of Epidemiology and Biostatistics, School of Public Health,

Nanjing Medical University, Nanjing, China

${ }^{3}$ Department of Breast, Nanjing Maternity and Child Health Hospital of

Nanjing Medical University, Nanjing, China

Full list of author information is available at the end of the article
}

have gained more focus recently because several studies have revealed that obesity is not only associated with malignancies (e.g., breast cancer and colorectal cancer) [6], cardiovascular disorders [7] and type 2 diabetes [8] but is also related to multiple infectious diseases [9].

Until recently, little was known about genetic determinants of obesity, with the exception of a few monogenic, extreme forms [10]. It is estimated that $40 \%$ to $90 \%$ variation in weight or obesity is attributed to genetic factors, according to twins or adoption studies [11-15]. Since then, genome-wide association studies (GWAS) have become available [16], and great advances have been made in exploring the association of genetic polymorphisms with human diseases and traits $[17,18]$. The first single nucleotide polymorphism (SNP) robustly related to body mass index (BMI) was mapped to one gene in 2007. This gene, now known as FTO (fat mass and obesity associated, Gene ID: 79068), has been repeatedly found to affect obesity in

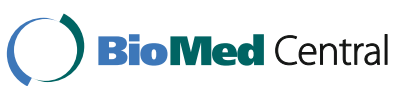


different populations [19-22]. The FTO gene is located on chromosome 16q12.2, which is well conserved in vertebrate species (e.g., fish and chicken) and plays a role in regulation of food intake [23]. This gene encodes a protein with a novel $\mathrm{C}$-terminal $\alpha$-helical domain and an $\mathrm{N}$-terminal double-strand $\beta$-helix domain. In vitro, the FTO protein can demethylate single-stranded RNA or DNA, but the exact physiological and function is still unknown [24]. The genetic polymorphisms rs 9939609 and rs8050136 within the FTO gene were found to be significantly associated with obesity in different populations [25-28], including the Chinese population [29-32].

Recent studies have further shown the effects of the FTO gene on the risk of BMI-related outcomes such as diabetes [33], neural tube defects [33] and Alzheimer's disease [34]. Although the effects of obesity on the development of metabolic and cardiovascular problems are well studied, much less is known about its impact on the infectious diseases. Obesity, similar to other states of malnutrition, is known to impair immune function, alter leukocyte counts and affect cell-mediated immune responses [35]. The impairment of the immune function leads to an increased susceptibility of the host to pathogens such as influenza, Mycobacterium tuberculosis, coxsackie virus, Helicobacter pylori and encephalomyocarditis virus [9]. We hypothesize that the FTO gene may play an important role in the risk of immune-related human infectious diseases such as tuberculosis. To test this hypothesis, we performed a case-control study to assess the association of two common FTO polymorphisms (rs9939609 and rs8050136) with pulmonary tuberculosis in a Chinese population.

\section{Methods}

\section{Study subjects and data collection}

This case-control study included 1625 pulmonary tuberculosis cases and 1570 unaffected controls recruited from Jiangsu province in China. All cases and controls were unrelated Han Chinese population. The cases were recruited from local Centers for Disease Control and Prevention and TB dispensaries. All cases were diagnosed by specialized doctors based on clinical signs, chest $\mathrm{x}$-ray examination, sputum smear tests or sputum culture. Controls were recruited through their participation in local community-based health examination programs. Those with a history of tuberculosis or malignancy were excluded. Controls were frequency matched to cases by sex and age. None of the cases and controls had an HIV-positive history. Trained interviewers administered a questionnaire to collect data on their demographic characteristics, tobacco smoking, alcohol consumption and health care-seeking history. A blood sample was collected from each participant for molecular analysis.

\section{Genotyping}

We extracted genomic DNA from peripheral blood samples by proteinase $\mathrm{K}$ digestion and a modified phenolchloroform protocol. The DNA was frozen at $-20^{\circ} \mathrm{C}$ until genotyping. Genotype determination of rs9939609 and rs8050136 in the FTO gene was carried out using TaqMan allelic discrimination assays on the ABI $7900 \mathrm{HT}$ RealTime PCR System (Applied Biosystems, Foster City, CA, USA) and was ascertained using the SDS software (version 2.3). The sequence specific forward and reverse primers and Taqman MGB probes are listed in Table 1. To avoid batch bias, we allocated DNA samples of cases and controls in each plate with no discrepancies between amplification reaction conditions. The overall calling rate was 99.2\% for rs9939609 and $98.4 \%$ for rs 8050136 . We randomly selected samples with different genotypes for gene sequencing. The consistent rate was $100 \%$.

\section{Statistical analysis}

Data were entered with EpiData 3.1 (Denmark) and analyzed using STATA 10.0 (StataCorp, College Station, TX, USA). Student's t-test (for continuous variables) and the $\chi^{2}$ test (for categorical variables) were used to analyze the differences in demographic variables and potential risk factors between cases and controls. Hardy-Weinberg equilibrium (HWE) was tested using a goodness-of-fit $\chi^{2}$ test by comparing the observed genotype frequencies with the

Table 1 Primers and probes used to detect SNPs

\begin{tabular}{|c|c|c|c|}
\hline SNPs & & Sequence $\left(5^{\prime}-3^{\prime}\right)$ & Detecting allele \\
\hline \multirow[t]{4}{*}{ rs9939609 } & $\mathrm{F}$ & CTAACATCAGTTATGCATTTAGAATGTCTG & \\
\hline & $\mathrm{R}$ & CCCACTCCATTTCTGACTGTTACC & \\
\hline & Probe- $T$ & FAM-CTGTGAATTITGTGATGC-MGB & Allele T \\
\hline & Probe-A & HEX-CTGTGAATTTAGTGATGCA-MGB & Allele A \\
\hline \multirow[t]{4}{*}{ rs8050136 } & $\mathrm{F}$ & CAGTGCCAGCTTCATAGCCTAGT & \\
\hline & $\mathrm{R}$ & CCATGAGTCCATCTCTACAGTITACC & \\
\hline & Probe- $C$ & HEX-CTGTGGCAATCAATAT-MGB & Allele C \\
\hline & Probe-A & FAM-CTGTGGCAATAAATA-MGB & Allele A \\
\hline
\end{tabular}


expected ones among the controls to ensure that the alleles were independently segregated. To evaluate the effects of genetic polymorphisms of the FTO gene on the risk of tuberculosis, we calculated odds ratios (ORs) and 95\% confidence intervals (CIs) using the unconditional logistic regression model. To avoid potential confounding, we further adjusted by age, sex, tobacco smoking and alcohol consumption. To analyze the effect of SNPs comprehensively, we applied three different genetic models: the additive model, the dominant model and the recessive model. Haplotype analysis on SNP rs9939609 and rs8050136 was performed using the phase 2.1 software.

\section{Ethical approval}

The study was approved by the Institutional Review Board of Nanjing Medical University. Informed consent was obtained for both the interviews and the blood samples.

\section{Results}

The genotype distributions of two SNPs were all in HWE in the controls $(\mathrm{P}=0.381$ for rs9939609; $\mathrm{P}=0.368$ for rs8050136). The general characteristics of cases and controls are shown in Table 2. In total, 1583 cases and 1544 controls were successfully genotyped and analyzed. Due to the frequency matching, there was no significant difference in the distribution of both age and sex between the groups. The proportion of ever smokers was 52.64\% among cases which was significantly higher than that among controls (34.84\%). However, alcohol consumption

Table 2 General characteristics of cases and controls

\begin{tabular}{|c|c|c|c|}
\hline Variables & $\begin{array}{l}\text { Control } \\
(n=1544) \\
n(\%)\end{array}$ & $\begin{array}{l}\text { Case } \\
(n=1583) \\
n(\%)\end{array}$ & $P$ \\
\hline Sex & & & 0.304 \\
\hline Male & $1118(72.41)$ & $1172(74.04)$ & \\
\hline Female & $426(27.59)$ & $411(25.96)$ & \\
\hline Age $($ mean $\pm S D)$ & $52.08 \pm 17.05$ & $52.13 \pm 17.71$ & 0.935 \\
\hline Tobacco smoking ${ }^{*}$ & & & $<0.001$ \\
\hline Never & $1006(65.16)$ & $745(47.36)$ & \\
\hline Ever & $538(34.84)$ & $828(52.64)$ & \\
\hline Alcohol consumption ${ }^{*}$ & & & 0.017 \\
\hline Never & $1116(73.81)$ & $1209(77.50)$ & \\
\hline Ever & $396(26.19)$ & $351(22.50)$ & \\
\hline Sputum smear test & & & - \\
\hline Positive & - & 1077(68.04) & \\
\hline Negative & - & $506(31.96)$ & \\
\hline Sputum culture & & & - \\
\hline Positive & - & $570(36.01)$ & \\
\hline $\begin{array}{l}\text { Negative or without } \\
\text { culture results }\end{array}$ & - & 1013(63.99) & \\
\hline
\end{tabular}

"There are some missing values. was inversely related to tuberculosis, where $22.50 \%$ of the cases vs. $26.19 \%$ of the controls had a history of alcohol consumption $(P=0.017)$.

There was a significant association between rs9939609 $(\mathrm{T}>\mathrm{A})$ and the risk of tuberculosis. Compared with the common genotype TT, those carrying the AA genotype had a significantly increased risk, with an OR of 3.77 (95\% CI: 2.26-6.28). After adjusting for potential confounders (sex, age, smoking and alcohol consumption), the association remained significant [adjusted OR: 3.57 (95\% CI: 2.13-6.01)]. As shown in Table 3, allele A carriers had a significantly increased risk among both clinical tuberculosis cases [OR: 1.26 (95\% CI: 1.08-1.48), $P=$ 0.004 ] and smear-positive cases [OR: 1.21 (95\% CI: 1.02-1.44), $P=0.030]$. The additive model showed that with each increased number of A alleles, the risk for tuberculosis increased accordingly [crude OR: 1.23 (95\% CI: 1.06-1.42), adjusted OR: 1.22 (95\% CI: 1.05-1.42)]. Stratified analysis revealed that the effect of AA genotype of rs9939609 on tuberculosis was more evident among men, ever smokers and alcohol drinkers (Tables 4 and 5). However, the heterogeneity wasn't significant across the strata. A significant association between the polymorphisms of rs8050136 and tuberculosis was only observed among never drinkers. Compared with the wild type $\mathrm{CC}$, the OR(95\% CI) was 0.22(0.06-0.83) for rs8050136 AA genotype. However, it was not significant after the Bonferroni multiple comparison correction.

Linkage disequilibrium (LD) was found between these SNPs of FTO $\left(\mathrm{D}^{\prime}=0.98, \mathrm{r}^{2}=0.94\right)$. A haplotype analysis was carried out, and the rs9939609A-rs8050136C haplotype significantly increased the risk of TB $(\mathrm{OR}=6.09,95 \%$ CI: 3.27-12.34) (Table 6).

To determine the potential functional effect of the SNP, we used the prediction tools SNPinfo (http://snpinfo. niehs.nih.gov/snpinfo/snpfunc.htm) and Regulome DB (http://www.regulomedb.org/). The RegulomeDB showed that rs8050136 was the binding site for the transcription factor (TF) EP300. The RegulomeDB score was 4 (supporting data: TF binding + DNase peak). No data were provided for the functional prediction of rs9939609.

\section{Discussion}

This case-control study investigated the association between genetic polymorphisms of the FTO gene and tuberculosis in a Chinese Han population. This is the first study, to our knowledge, revealing the effect of genetic variations of intron 1 SNP rs9939609 of FTO on the risk of tuberculosis.

Immunocompetence is dependent on nutritional status and can be negatively affected by malnutrition and related disorders, including obesity. Epidemiological data support the hypothesis that obesity can affect immune function in humans [9]. Obesity has been shown to be 
Table 3 The association between two SNPs within the FTO gene and the risk of tuberculosis

\begin{tabular}{|c|c|c|c|c|c|c|c|c|c|c|c|}
\hline \multirow[t]{2}{*}{ SNPs } & \multirow{2}{*}{$\begin{array}{l}\text { Control } \\
(n=1544) \\
n(\%)\end{array}$} & \multicolumn{5}{|c|}{ Total cases $(n=1583)$} & \multicolumn{5}{|c|}{ Smear-positive cases $(n=1077)$} \\
\hline & & n (\%) & cOR $(95 \% \mathrm{Cl})$ & $P$ & aOR $(95 \% \mathrm{Cl})$ & $P$ & n (\%) & COR $(95 \% \mathrm{Cl})$ & $P$ & aOR $(95 \% \mathrm{Cl})$ & $P$ \\
\hline \multicolumn{12}{|c|}{ rs9939609 (T > A) } \\
\hline$\pi$ & 1250(80.91) & $1258(79.52)$ & 1 & & 1 & & 856(79.48) & 1 & & 1 & \\
\hline AT & $275(17.86)$ & 253(15.94) & $0.91(0.75-1.10)$ & 0.316 & $0.91(0.74-1.10)$ & 0.316 & $182(16.90)$ & $0.96(0.78-1.18)$ & 0.723 & $0.96(0.77-1.19)$ & 0.699 \\
\hline AA & $19(1.23)$ & $72(4.54)$ & $3.77(2.26-6.28)$ & $<0.001$ & $3.57(2.13-6.01)$ & $<0.001$ & 39(3.62) & $2.99(1.73-5.17)$ & $<0.001$ & $2.84(1.61-5.01)$ & $<0.001$ \\
\hline T allele & 2767(89.84) & $2777(87.35)$ & 1 & & & & 1894(87.93) & 1 & & & \\
\hline A allele & $313(10.16)$ & $397(12.51)$ & $1.26(1.08-1.48)$ & 0.004 & & & $260(12.07)$ & $1.21(1.02-1.44)$ & 0.030 & & \\
\hline Add & & & $1.23(1.06-1.42)$ & 0.006 & $1.22(1.05-1.42)$ & 0.011 & & $1.20(1.01-1.41)$ & 0.035 & $1.18(0.99-1.40)$ & 0.059 \\
\hline Dom & & & $1.10(0.92-1.31)$ & 0.296 & $1.09(0.91-1.30)$ & 0.374 & & $1.10(0.90-1.34)$ & 0.343 & $1.09(0.89-1.33)$ & 0.424 \\
\hline $\operatorname{Rec}$ & & & $3.82(2.30-6.37)$ & $<0.001$ & $3.64(2.17-6.10)$ & $<0.001$ & & $3.02(1.73-5.25)$ & $<0.001$ & $2.86(1.62-5.04)$ & $<0.001$ \\
\hline \multicolumn{12}{|c|}{ rs8050136 (C > A) } \\
\hline $\mathrm{CC}$ & 1250(80.91) & 1265(79.96) & 1 & & 1 & & 863(80.13) & 1 & & 1 & \\
\hline$A C$ & 282(18.31) & $311(19.60)$ & $1.09(0.91-1.30)$ & 0.347 & $1.08(0.19-1.26)$ & 0.408 & 210(19.5) & $1.08(0.89-1.32)$ & 0.448 & $1.07(0.87-1.32)$ & 0.513 \\
\hline AA & $12(0.78)$ & $7(0.44)$ & $0.58(0.23-1.47)$ & 0.248 & $0.48(0.19-1.26)$ & 0.136 & $4(0.37)$ & $0.48(0.16-1.50)$ & 0.209 & $0.40(0.13-1.28)$ & 0.123 \\
\hline C allele & 2774(90.06) & 2849(89.76) & 1 & & & & 1936(89.88) & 1 & & & \\
\hline A allele & $306(9.94)$ & $325(10.24)$ & $1.03(0.88-1.22)$ & 0.690 & & & $218(10.12)$ & $1.02(0.85-1.23)$ & 0.826 & & \\
\hline Add & & & $1.04(0.88-1.23)$ & 0.632 & $1.02(0.86-1.22)$ & 0.804 & & $1.03(0.85-1.24)$ & 0.789 & $1.01(0.83-1.22)$ & 0.957 \\
\hline Dom & & & $1.07(0.90-1.28)$ & 0.461 & $1.05(0.88-1.27)$ & 0.569 & & $1.06(0.87-1.28)$ & 0.590 & $1.04(0.85-1.28)$ & 0.702 \\
\hline Rec & & & $0.57(0.22-1.44)$ & 0.234 & $0.48(0.18-1.24)$ & 0.127 & & $0.48(0.15-1.48)$ & 0.200 & $0.40(0.12-1.26)$ & $0.117^{*}$ \\
\hline
\end{tabular}

Add additive model, Dom dominant model, Rec recessive model, cOR crude odds ratio, Cl confidence interval, aOR adjusted odds ratio, adjusted for age, sex smoking and alcohol drinking 
Table 4 The association between two SNPs within the FTO gene and the risk of tuberculosis stratified by sex

\begin{tabular}{|c|c|c|c|c|c|c|}
\hline \multirow[t]{2}{*}{ SNPs } & \multicolumn{3}{|c|}{ Male $(n=2290)$} & \multicolumn{3}{|c|}{ Female $(n=837)$} \\
\hline & n (\%) & OR $(95 \% \mathrm{Cl})^{\mathrm{a}}$ & $P^{\mathrm{a}}$ & n (\%) & OR $(95 \% \mathrm{CI})^{\mathrm{a}}$ & $P^{a}$ \\
\hline \multicolumn{7}{|c|}{ rs9939609 (T > A) } \\
\hline$\pi$ & 1823(79.61) & 1 & & $685(81.84)$ & 1 & \\
\hline AT & $396(17.29)$ & $0.93(0.74-1.16)$ & 0.508 & $132(15.77)$ & $0.85(0.58-1.24)$ & 0.397 \\
\hline AA & $71(3.10)$ & $4.15(2.23-7.70)$ & $<0.001$ & $20(2.39)$ & $2.46(0.93-6.47)$ & 0.069 \\
\hline Add & & $1.27(1.06-1.51)$ & 0.008 & & $1.09(0.80-1.47)$ & 0.590 \\
\hline Dom & & $1.13(0.91-1.39)$ & 0.257 & & $0.98(0.68-1.40)$ & 0.893 \\
\hline $\operatorname{Rec}$ & & $4.20(2.27-7.79)$ & $<0.001$ & & $2.52(0.96-6.63)$ & 0.061 \\
\hline \multicolumn{7}{|c|}{ rs8050136 (C>A) } \\
\hline CC & $1827(79.78)$ & 1 & & $688(82.20)$ & 1 & \\
\hline$A C$ & 448 (19.56) & $1.12(0.90-1.39)$ & 0.301 & $145(17.32)$ & $0.98(0.68-1.42)$ & 0.924 \\
\hline AA & $15(0.66)$ & $0.53(0.18-1.52)$ & 0.237 & $4(0.48)$ & $0.35(0.04-3.38)$ & 0.364 \\
\hline Add & & $1.06(0.86-1.29)$ & 0.591 & & $0.93(0.66-1.32)$ & 0.692 \\
\hline Dom & & $1.09(0.88-1.35)$ & 0.413 & & $0.51(0.18-1.49)$ & 0.220 \\
\hline $\operatorname{Rec}$ & & $0.51(0.18-1.49)$ & 0.220 & & $0.35(0.04-3.38)$ & 0.365 \\
\hline
\end{tabular}

adjusted for age, sex smoking and alcohol drinking where appropriate, Add additive model, Dom dominant model, Rec recessive model, OR odds ratio, $\mathrm{Cl}$ confidence interval.

influenced by genetic determinants. In 2007, the first common genetic variant in the FTO gene was identified. FTO is a large gene with nine exons spanning more than $400 \mathrm{~kb}$ on chromosome 16, and all of the SNPs identified so far are located in the first and largest intron of the gene [36]. FTO is predominantly expressed in the brain, particularly in the hypothalamus, and plays a key role in the control of energy homeostasis [37]. In studies with mice, the expression of FTO in the arcuate nucleus of hypothalamus decreased following a 48-hour fast and increased after 10 weeks of exposure to a high-fat diet $[38,39]$. In humans, FTO appears to be essential for the normal development of major organ systems, such as the central nervous and cardiovascular system [36]. The first SNP strongly associated with BMI and obesity was located in the FTO gene, and this has been subsequently replicated in multiple populations [25]. Since Fralying et al. found that the variant of rs9939609 could increase the risk of developing obesity by $31 \%$, numerous studies covering multiple populations subsequently focused on this SNP [40-42]. Li et al. genotyped rs9939609 in a Chinese population and found that the A allele was strongly associated with obesity and overweight [43]. The odds ratios for the allele A vs. T were 1.447 for obesity vs. normal weight (95\% CI: 1.104-1.896) and 1.363 for overweight vs. normal weight (95\% CI: 1.149-1.617) [43]. Xi et al. genotyped 11 SNPs of FTO gene in the Chinese children (6-18 years) and replicated the association of FTO rs9939609 with the risk of central obesity (OR:1.29, 95\% CI:1.101.50) [40]. The association between rs9939609 polymorphism and obesity was also supported by other studies in China $[29,41,42]$. Though results of our present study do not directly support the role of FTO in obesity risk, it is plausible that its effect on tuberculosis occurs through obesity-related immunocompetence.

In addition to obesity, the FTO rs9939609 polymorphism was found to be associated with type 2 diabetes in Vietnamese (OR per A allele $=1.61,95 \% \mathrm{CI}$ : 1.06-2.44) [44], South Asians (OR per A allele $=1.18$, 95\% CI: 1.07 1.30) [45], and Chinese (OR for allele $\mathrm{A}=1.31$, 95\% CI: 1.10-1.55) [43]. Interestingly, there is growing evidence regarding diabetes as a risk factor for tuberculosis, and it might affect a patient's disease presentation and treatment response $[4,46,47]$. Uncontrolled diabetics seem to have more cavities and higher positive smear rates and to show a lack of culture conversion after two months of antituberculosis therapy [48]. At the public health level, the diabetes epidemic could be one reason why efforts to reduce the global incidence of tuberculosis are having little effect, despite the high case detection rates and cure rates [47].

In this study, a LD was found between rs9939609 and rs8050136. The haplotype rs9939609A-rs8050136C was related with an increased risk of tuberculosis. Previous studies have revealed that individuals who carry a particular SNP allele at one site often predictably carry specific alleles at other nearby sites. This correlation is known as LD and a particular combination of alleles along a chromosome is termed as the haplotype [49]. The relationship between causal mutations and the haplotypes have been regarded as a tool for genetic researches--first finding association to a haplotype, and then subsequently identifying the causal mutations that it carries [49]. 
Table 5 The association between two SNPs within the FTO gene and the risk of tuberculosis stratified by smoking and alcohol drinking

\begin{tabular}{|c|c|c|c|c|c|c|c|c|c|c|c|c|}
\hline \multirow[t]{3}{*}{ SNPs } & \multicolumn{6}{|l|}{ Smoking } & \multicolumn{6}{|c|}{ Alcohol drinking } \\
\hline & \multicolumn{3}{|c|}{ Never $(n=1751)$} & \multicolumn{3}{|c|}{ Ever $(n=1366)$} & \multicolumn{3}{|c|}{ Never $(n=2325)$} & \multicolumn{3}{|c|}{ Ever $(n=747)$} \\
\hline & n (\%) & OR $(95 \% \mathrm{Cl})^{\mathrm{a}}$ & $P^{a}$ & n (\%) & OR $(95 \% \mathrm{Cl})^{\mathrm{a}}$ & $P^{a}$ & n (\%) & OR $(95 \% \mathrm{Cl})^{\mathrm{a}}$ & $P^{a}$ & $\mathrm{n}(\%)$ & OR $(95 \% \mathrm{Cl})^{\mathrm{a}}$ & $P^{a}$ \\
\hline \multicolumn{13}{|c|}{ rs9939609 (T > A) } \\
\hline$\pi$ & $1421(81.15)$ & 1 & & 1078(78.92) & 1 & & $1868(80.34)$ & 1 & & $594(79.52)$ & 1 & \\
\hline AT & 292(16.68) & $0.98(0.76-1.28)$ & 0.906 & 235(17.20) & $0.81(0.60-1.09)$ & 0.163 & 394 (16.95) & $0.91(0.72-1.13)$ & 0.391 & 125 (16.73) & $0.88(0.59-1.31)$ & 0.536 \\
\hline AA & $38(2.17)$ & $2.87(1.43-5.77)$ & 0.003 & $53(3.88)$ & $4.69(2.08-10.59)$ & $<0.001$ & $63(2.71)$ & $2.42(1.36-4.32)$ & 0.003 & $28(3.75)$ & $15.39(3.78-134.54)$ & $<0.001$ \\
\hline Add & & $1.20(0.98-1.48)$ & 0.083 & & $1.23(0.99-1.54)$ & 0.065 & & $1.12(0.94-1.34)$ & 0.200 & & $1.51(1.13-2.03)$ & 0.006 \\
\hline Dom & & $1.11(0.87-1.42)$ & 0.388 & & $1.05(0.80-1.38)$ & 0.720 & & $1.03(0.83-1.27)$ & 0.799 & & $1.27(0.88-1.82)$ & 0.196 \\
\hline $\operatorname{Rec}$ & & $2.88(1.44-5.77)$ & 0.003 & & $4.86(2.16-10.96)$ & $<0.001$ & & $2.46(1.39-4.39)$ & 0.002 & & 14.65(3.44-62.34) & $<0.001$ \\
\hline \multicolumn{13}{|c|}{ rs8050136 (C>A) } \\
\hline CC & 1428(81.55) & 1 & & 1078(78.92) & 1 & & $1878(80.77)$ & 1 & & 591 (77.49) & 1 & \\
\hline$A C$ & $316(18.05)$ & $1.13(0.88-1.45)$ & 0.336 & $276(20.20)$ & $1.02(0.77-1.35)$ & 0.888 & 434 (18.67) & $1.05(0.84-1.30)$ & 0.673 & $150(20.08)$ & $1.18(0.82-1.69)$ & 0.383 \\
\hline AA & $7(0.40)$ & $0.22(0.03-1.81)$ & 0.157 & $12(0.88)$ & $0.68(0.21-2.17)$ & 0.512 & $13(0.56)$ & $0.22(0.06-0.83)$ & 0.025 & $6(0.80)$ & $2.12(0.38-11.68)$ & 0.389 \\
\hline Add & & $1.06(0.83-1.34)$ & 0.644 & & $0.98(0.76-1.27)$ & 0.896 & & $0.96(0.78-1.18)$ & 0.692 & & $1.21(0.87-1.70)$ & 0.260 \\
\hline Dom & & $1.10(0.86-1.41)$ & 0.460 & & $1.00(0.76-1.32)$ & 0.988 & & $1.00(0.81-1.24)$ & 0.964 & & $1.20(0.84-1.72)$ & 0.313 \\
\hline $\operatorname{Rec}$ & & $0.21(0.03-1.76)$ & 0.151 & & $0.67(0.21-2.16)$ & 0.507 & & $0.22(0.06-0.82)$ & 0.024 & & $2.05(0.37-11.29)$ & 0.409 \\
\hline
\end{tabular}


Table 6 Haplotype analysis of rs9939609 and rs8050136

\begin{tabular}{lllll}
\hline Haplotype $^{*}$ & Case & Control & OR (95\% Cl) & $P$ \\
& $\mathbf{n}(\%)$ & $\mathbf{n}(\%)$ & & \\
\hline TC & $2768(87.43)$ & $2770(89.70)$ & 1 & \\
AA & $324(10.23)$ & $301(9.75)$ & $1.08(0.91-1.28)$ & 0.379 \\
AC & $73(2.31)$ & $12(0.39)$ & $6.09(3.27-12.34)$ & $<0.001$ \\
TA & $1(0.03)$ & $5(0.16)$ & $0.20(0.004-1.79)$ & 0.219 \\
\hline
\end{tabular}

${ }^{*}$ rs9939609-rs8050136.

In the present study, we observed the role of common FTO rs9939609 SNP in the risk of tuberculosis, which supports the hypothesis that genetic polymorphisms of the FTO gene affect the host's susceptibility to infectious diseases. We believe that the effect of FTO-rs9939609 on the risk of tuberculosis may not solely be attributed to its role in the risk of obesity. The altered human immune function related to these genetic variants can explain, at least in part, why some people resist tuberculosis infection more successfully than others [50,51]. This finding may help distinguish individuals who are at higher risks for tuberculosis and implement effective interventions to prevent and control the disease.

HWE test is commonly used as an initial quality check procedure in genetic association studies. Departure from HWE (DHWE) may suggest a higher risk of genotyping errors [52]. In the current study, HWE was observed among controls for either the SNP rs9939609 or the SNP rs8050136, but the P value from classical goodnessof-fit test was less than 0.05 in cases. In general, the HWE test assumes that the genotypes are sampled from the general population, and therefore the HWE tests are performed based on the controls. If the entire population is in perfect HWE, the presence of a genetic association implies that neither cases nor controls can be in HWE. Because the proportion of affected subjects in a population is small, the degree of DHWE is expected to be stronger in cases than in controls. Therefore, as an indicator of genotyping quality, compatibility with HWE should be investigated in control groups only [53]. In cohort studies, no DHWE is expected, and therefore the entire sample should be genotyped for testing HWE [53]. Recently, some authors have shown that when the disease is common in the general population, the controls do not accurately represent the general population. Therefore, using only controls for HWE testing can result in highly inflated type I error and might lead investigators to discard potential causal SNPs [52]. Wittke-Thompson et al. suggest that if a DHWE in cases or in both cases and controls is detected, it does not necessarily imply genotyping errors [54]. Rather than discarding the data, the underlying disease-genotype association should be investigated. The association may explain the observed DHWE. If not, other possible explanations such as "genotyping error, chance, and failure of assumptions underlying HWE expectations" should be explored [55]. To detect genotyping errors, repeated genotyping of the same samples is preferable over HWE testing. In the current study, we allocated DNA samples of cases and controls in each plate with no discrepancies between amplification reaction conditions. We randomly selected $5 \%$ samples to re-genotype and the consistent rate was more than $99 \%$. We also randomly selected samples with different genotypes for gene sequencing and the consistent rate was $100 \%$. Thus we believe that the DHWE in cases can't be attributed to the genotyping errors.

There are several limitations in this study. First, due to a case-control study design, BMI prior to the diagnosis of tuberculosis was absent, which restricted an in-depth analysis of the ancillary effect of FTO variants on obesity. Second, we only selected two SNPs in the FTO gene. Other polymorphisms and their interactions with environmental factors should also be considered [56]. Third, rs9939609 is located in the intron region of the FTO gene and may not be the true causal variant. Based on the RegulomeDB database, we observed a minimal binding evidence of rs8050136, which has a strong LD with rs9939609. We hypothesize that the SNP rs9939609 may be in linkage with the true functional SNP(s). Further work with both knockout and overexpression models of FTO and neighboring genes is likely to provide the most fruitful approach to understand the mechanisms and pathways through which these variants influence the risk of tuberculosis.

\section{Conclusions}

Taken together, our results suggest that the FTO rs9939609 genetic polymorphism and the haplotype (rs9939609Ars8050136C) are involved in the risk of tuberculosis in the Chinese population. Future studies should include a comprehensive sequencing analysis to identify the specific causative sequence variants underlying the observed associations. In future studies, nutritional status and environmental factors will be essential for elucidating gene-environment interactions.

\section{Competing interests}

The authors declare that they have no competing interests.

\section{Authors' contributions}

YF and JW conceived the idea. YF, FW, HP, SQ, JL, LW, CL and JW were involved in data collection and genotyping. YF and JW participated in the data analysis and drafted the manuscript. All authors read and approved the final manuscript.

\section{Acknowledgement}

I would like to thank Dr. Stefanie Röhrs (Institute of Tropical Medicine \& International Health, Charité - Universitätsmedizin Berlin) for editorial support with the manuscript. This study was partly supported by the National Natural Science Foundation of China (81473027, 81072351), Jiangsu Science Supported Planning/Social Development Foundation (BE2011841), Zhenjiang 
Key Lab for Drug Resistant Tuberculosis (SS201320004) and Priority Academic Program Development of Jiangsu Higher Education Institutions (PAPD). The funders had no role in study design, data collection and analysis, decision to publish, or preparation of the manuscript.

\section{Author details}

${ }^{1}$ Division of Parasite Disease Intervention, Zhejiang Provincial Center for Disease Control and Prevention, Zhejiang, China. ${ }^{2}$ Department of Epidemiology and Biostatistics, School of Public Health, Nanjing Medical University, Nanjing, China. ${ }^{3}$ Department of Breast, Nanjing Maternity and Child Health Hospital of Nanjing Medical University, Nanjing, China. ${ }^{4}$ Department of Tuberculosis, Third Hospital of Zhenjiang City, Zhenjiang, China.

Received: 17 July 2013 Accepted: 27 October 2014

Published online: 07 November 2014

\section{References}

1. Ladefoged K, Rendal T, Skifte T, Andersson M, Soborg B, Koch A: Risk factors for tuberculosis in Greenland: case-control study. Int I Tuberc Lung Dis 2011, 15(1):44-49.

2. Murray M, Oxlade $\mathrm{O}$, Lin HH: Modeling social, environmental and biological determinants of tuberculosis. Int I Tuberc Lung Dis 2011, 15(Suppl 2):S64-S70

3. Faurholt-Jepsen D, Range N, Praygod G, Jeremiah K, Faurholt-Jepsen M, Aabye MG, Changalucha J, Christensen DL, Pipper CB, Krarup H, Witte DR, Andersen $A B$, Friis $\mathrm{H}$ : Diabetes is a risk factor for pulmonary tuberculosis: a case-control study from Mwanza, Tanzania. PLoS One 2011, 6(8):e24215.

4. Dooley KE, Chaisson RE: Tuberculosis and diabetes mellitus: convergence of two epidemics. Lancet Infect Dis 2009, 9(12):737-746.

5. Wang J, Shen H: Review of cigarette smoking and tuberculosis in China: intervention is needed for smoking cessation among tuberculosis patients. BMC Public Health 2009, 9:292.

6. Anderson JC: Editorial: body mass index and colorectal adenomas. Am J Gastroenterol 2012, 107(8):1187-1188.

7. Kenchaiah S, Evans JC, Levy D, Wilson PW, Benjamin EJ, Larson MG, Kannel WB, Vasan RS: Obesity and the risk of heart failure. N Engl J Med 2002, 347(5):305-313.

8. Sanada H, Yokokawa H, Yoneda M, Yatabe J, Sasaki Yatabe M, Williams SM, Felder RA, Jose PA: High body mass index is an important risk factor for the development of type 2 diabetes. Intern Med 2012, 51(14):1821-1826.

9. Karlsson EA, Beck MA: The burden of obesity on infectious disease. Exp Biol Med (Maywood) 2010, 235(12):1412-1424.

10. Fall T, Ingelsson E: Genome-wide association studies of obesity and metabolic syndrome. Mol Cell Endocrinol 2014, 382(1):740-757.

11. Stunkard AJ, Foch $\pi$, Hrubec Z: A twin study of human obesity. JAMA 1986, 256(1):51-54

12. Stunkard AJ, Sorensen TI, Hanis C, Teasdale TW, Chakraborty R, Schull WJ, Schulsinger F: An adoption study of human obesity. N Engl J Med 1986, 314(4):193-198.

13. Hjelmborg J, Fagnani C, Silventoinen K, McGue M, Korkeila M, Christensen K, Rissanen A, Kaprio J: Genetic influences on growth traits of BMI: a longitudinal study of adult twins. Obesity (Silver Spring) 2008, 16(4):847-852.

14. Maes HH, Neale MC, Eaves $\sqcup$ : Genetic and environmental factors in relative body weight and human adiposity. Behav Genet 1997, 27(4):325-351.

15. Wardle J, Carnell S, Haworth CM, Plomin R: Evidence for a strong genetic influence on childhood adiposity despite the force of the obesogenic environment. Am J Clin Nutr 2008, 87(2):398-404.

16. Klein RJ, Zeiss C, Chew EY, Tsai JY, Sackler RS, Haynes C, Henning AK, SanGiovanni JP, Mane SM, Mayne ST, Bracken MB, Ferris FL, Ott J, Barnstable $\mathrm{C}$, Hoh J: Complement factor $\mathrm{H}$ polymorphism in age-related macular degeneration. Science 2005, 308(5720):385-389.

17. Thye T, Vannberg FO, Wong SH, Owusu-Dabo E, Osei I, Gyapong J, Sirugo G, Sisay-Joof F, Enimil A, Chinbuah MA, Floyd S, Warndorff DK, Sichali L, Malema S, Crampin AC, Ngwira B, Teo YY, Small K, Rockett K, Kwiatkowski D, Fine PE, Hill PC, Newport M, Lienhardt C, Adegbola RA, Corrah T, Ziegler A, African TBGC, Wellcome Trust Case Control C, Morris AP, et al: Genomewide association analyses identifies a susceptibility locus for tuberculosis on chromosome 18q11.2. Nat Genet 2010, 42(9):739-741.

18. Thye T, Owusu-Dabo E, Vannberg FO, van Crevel R, Curtis J, Sahiratmadja E, Balabanova Y, Ehmen C, Muntau B, Ruge G, Sievertsen J, Gyapong J,
Nikolayevskyy V, Hill PC, Sirugo G, Drobniewski F, van de Vosse E, Newport M, Alisjahbana B, Nejentsev S, Ottenhoff TH, Hill AV, Horstmann RD, Meyer CG: Common variants at $11 \mathrm{p} 13$ are associated with susceptibility to tuberculosis. Nat Genet 2012, 44(3):257-259.

19. Hennig BJ, Fulford AJ, Sirugo G, Rayco-Solon P, Hattersley AT, Frayling TM, Prentice AM: FTO gene variation and measures of body mass in an African population. BMC Med Genet 2009, 10:21.

20. Peeters A, Beckers S, Verrijken A, Roevens P, Peeters P, Van Gaal L, Van Hul $W$ : Variants in the FTO gene are associated with common obesity in the Belgian population. Mol Genet Metab 2008, 93(4):481-484.

21. Hinney A, Nguyen $T$, Scherag A, Friedel S, Bronner G, Muller TD, Grallert $H$, Illig T, Wichmann HE, Rief W, Schafer H, Hebebrand J: Genome wide association (GWA) study for early onset extreme obesity supports the role of fat mass and obesity associated gene (FTO) variants. PLoS One 2007, 2(12):e1361.

22. Hotta K, Nakata Y, Matsuo T, Kamohara S, Kotani K, Komatsu R, Itoh N, Mineo I, Wada J, Masuzaki H, Yoneda M, Nakajima A, Miyazaki S, Tokunaga K, Kawamoto M, Funahashi T, Hamaguchi K, Yamada K, Hanafusa T, Oikawa S, Yoshimatsu H, Nakao K, Sakata T, Matsuzawa Y, Tanaka K, Kamatani N, Nakamura Y: Variations in the FTO gene are associated with severe obesity in the Japanese. J Hum Genet 2008, 53(6):546-553.

23. Fredriksson R, Hagglund M, Olszewski PK, Stephansson O, Jacobsson JA, Olszewska AM, Levine AS, Lindblom J, Schioth HB: The obesity gene, FTO, is of ancient origin, up-regulated during food deprivation and expressed in neurons of feeding-related nuclei of the brain. Endocrinology 2008, 149(5):2062-2071.

24. Gao $X$, Shin YH, Li M, Wang F, Tong Q, Zhang P: The fat mass and obesity associated gene FTO functions in the brain to regulate postnatal growth in mice. PLoS One 2010, 5(11):e14005.

25. Frayling $T M$, Timpson $N J$, Weedon $M N$, Zeggini E, Freathy RM, Lindgren $C M$, Perry JR, Elliott KS, Lango H, Rayner NW, Shields B, Harries LW, Barrett JC, Ellard S, Groves CJ, Knight B, Patch AM, Ness AR, Ebrahim S, Lawlor DA, Ring SM, Ben-Shlomo Y, Jarvelin MR, Sovio U, Bennett AJ, Melzer D, Ferrucci L, Loos RJ, Barroso I, Wareham NJ, et al: A common variant in the FTO gene is associated with body mass index and predisposes to childhood and adult obesity. Science 2007, 316(5826):889-894.

26. Hunt SC, Stone S, Xin Y, Scherer CA, Magness CL, ladonato SP, Hopkins PN, Adams TD: Association of the FTO gene with BMI. Obesity (Silver Spring) 2008, 16(4):902-904

27. Xi B, Mi J: FTO polymorphisms are associated with obesity but not with diabetes in East Asian populations: a meta-analysis. Biomed Environ Sci 2009, 22(6):449-457.

28. Cheung CY, Tso AW, Cheung BM, Xu A, Ong KL, Law LS, Wat NM, Janus ED, Sham PC, Lam KS: Genetic variants associated with persistent central obesity and the metabolic syndrome in a 12-year longitudinal study. Eur J Endocrinol 2011, 164(3):381-388.

29. Huang W, Sun Y, Sun J: Combined effects of FTO rs9939609 and MC4R rs 17782313 on obesity and BMI in Chinese Han populations. Endocrine 2011, 39(1):69-74.

30. Cheung CY, Tso AW, Cheung BM, Xu A, Ong KL, Fong CH, Wat NM, Janus ED, Sham PC, Lam KS: Obesity susceptibility genetic variants identified from recent genome-wide association studies: implications in a chinese population. J Clin Endocrinol Metab 2010, 95(3):1395-1403.

31. Ng MC, Park KS, Oh B, Tam CH, Cho YM, Shin HD, Lam VK, Ma RC, So WY, Cho YS, Kim HL, Lee HK, Chan JC, Cho NH: Implication of genetic variants near TCF7L2, SLC30A8, HHEX, CDKAL1, CDKN2A/B, IGF2BP2, and FTO in type 2 diabetes and obesity in 6,719 Asians. Diabetes 2008, 57(8):2226-2233.

32. Tan JT, Dorajoo R, Seielstad M, Sim XL, Ong RT, Chia KS, Wong TY, Saw SM Chew SK, Aung T, Tai ES: FTO variants are associated with obesity in the Chinese and Malay populations in Singapore. Diabetes 2008, 57(10):2851-2857.

33. Chen G, Xu Y, Lin Y, Lai X, Yao J, Huang B, Chen Z, Huang H, Fu X, Lin L, Lai S, Wen J: Association study of genetic variants of 17 diabetes-related genes/loci and cardiovascular risk and diabetic nephropathy in the Chinese She population. J Diabetes 2013, 5(2):136-145.

34. Reitz C, Tosto G, Mayeux R, Luchsinger JA: Genetic variants in the Fat and Obesity Associated (FTO) gene and risk of Alzheimer's disease. PLoS One 2012, 7(12):e50354.

35. de Heredia FP, Gomez-Martinez S, Marcos A: Obesity, inflammation and the immune system. Proc Nutr Soc 2012, 71(2):332-338. 
36. Tung YC, Yeo GS: From GWAS to biology: lessons from FTO. Ann N Y Acad Sci 2011, 1220:162-171.

37. Coll AP, Yeo GS, Farooqi IS, O'Rahilly S: SnapShot: the hormonal control of food intake. Cell 2008, 135(3):572 e571-572.

38. Gerken T, Girard CA, Tung YC, Webby CJ, Saudek V, Hewitson KS, Yeo GS, McDonough MA, Cunliffe S, McNeill LA, Galvanovskis J, Rorsman P, Robins P, Prieur X, Coll AP, Ma M, Jovanovic Z, Faroogi IS, Sedgwick B, Barroso I, Lindahl T, Ponting CP, Ashcroft FM, O'Rahilly S, Schofield CJ: The obesityassociated FTO gene encodes a 2-oxoglutarate-dependent nucleic acid demethylase. Science 2007, 318(5855):1469-1472.

39. Tung YC, Ayuso E, Shan X, Bosch F, O'Rahilly S, Coll AP, Yeo GS: Hypothalamic-specific manipulation of Fto, the ortholog of the human obesity gene FTO, affects food intake in rats. PLoS One 2010, 5(1):e8771.

40. Xi B, Cheng H, Shen Y, Chandak GR, Zhao X, Hou D, Wu L, Wang X, Mi J: Study of 11 BMI-Associated Loci Identified in GWAS for associations with central obesity in the Chinese children. PLoS One 2013, 8(2):e56472.

41. Wang J, Mei H, Chen W, Jiang Y, Sun W, Li F, Fu Q, Jiang F: Study of eight GWAS-identified common variants for association with obesity-related indices in Chinese children at puberty. Int J Obes (Lond) 2012, 36(4):542-547.

42. Sun Y, Sun J, Wang X, You W, Yang M: Variants in the fat mass and obesity associated (FTO) gene are associated with obesity and C-reactive protein levels in Chinese Han populations. Clin Invest Med 2010, 33(6):E405-E412.

43. Li X, Song F, Jiang H, Zhang M, Lin J, Bao W, Yao P, Yang X, Hao L, Liu L: A genetic variation in the fat mass- and obesity-associated gene is associated with obesity and newly diagnosed type 2 diabetes in a Chinese population. Diabetes Metab Res Rev 2010, 26(2):128-132.

44. Binh TQ, Phuong PT, Nhung BT, Thoang DD, Lien HT, Thanh DV: Association of the common FTO-rs9939609 polymorphism with type 2 diabetes, independent of obesity-related traits in a Vietnamese population. Gene 2013, 513(1):31-35.

45. Rees SD, Islam M, Hydrie MZ, Chaudhary B, Bellary S, Hashmi S, O'Hare JP, Kumar S, Sanghera DK, Chaturvedi N, Barnett AH, Shera AS, Weedon MN, Basit A, Frayling TM, Kelly MA, Jafar TH: An FTO variant is associated with Type 2 diabetes in South Asian populations after accounting for body mass index and waist circumference. Diabet Med 2011, 28(6):673-680.

46. Jeon $C Y$, Murray MB: Diabetes mellitus increases the risk of active tuberculosis: a systematic review of 13 observational studies. PLOS Med 2008, 5(7):e152.

47. Maurice J: WHO framework targets tuberculosis-diabetes link. Lancet 2011, 378(9798):1209-1210.

48. Yew WW, Lange C, Leung CC: Treatment of tuberculosis: update 2010. Eur Respir J 2011, 37(2):441-462.

49. International HapMap C: A haplotype map of the human genome. Nature 2005, 437(7063):1299-1320.

50. Yim JJ, Selvaraj P: Genetic susceptibility in tuberculosis. Respirology 2010, 15(2):241-256

51. Pantelidis P: Tuberculosis: an ancient disease still confusing our genes. Respiration 2005, 72(4):347-348.

52. Wang J, Shete S: Testing Hardy-Weinberg proportions in a frequencymatched case-control genetic association study. PLoS One 2011 6(11):e27642.

53. Ziegler A, Van Steen K, Wellek S: Investigating Hardy-Weinberg equilibrium in case-control or cohort studies or meta-analysis. Breast Cancer Res Treat 2011, 128(1):197-201.

54. Wittke-Thompson JK, Pluzhnikov A, Cox NJ: Rational inferences about departures from Hardy-Weinberg equilibrium. Am J Hum Genet 2005, 76(6):967-986.

55. Yu C, Zhang S, Zhou C, Sile S: A likelihood ratio test of population HardyWeinberg equilibrium for case-control studies. Genet Epidemiol 2009, 33(3):275-280.

56. Möller M, Hoal EG: Current findings, challenges and novel approaches in human genetic susceptibility to tuberculosis. Tuberculosis (Edinb) 2010, 90(2):71-83.

doi:10.1186/s12879-014-0592-2

Cite this article as: Feng et al:: Obesity-associated gene FTO rs9939609 polymorphism in relation to the risk of tuberculosis. BMC Infectious Diseases 2014 14:592.

\section{Submit your next manuscript to BioMed Central and take full advantage of:}

- Convenient online submission

- Thorough peer review

- No space constraints or color figure charges

- Immediate publication on acceptance

- Inclusion in PubMed, CAS, Scopus and Google Scholar

- Research which is freely available for redistribution 